\title{
Changes in Cisternal Udder Compartment Induced by Milking Interval in Dairy Goats Milked Once or Twice Daily
}

\author{
A. A. K. Salama, ${ }^{1,2}$ G. Caja, ${ }^{1}$ X. Such, ${ }^{1}$ S. Peris,${ }^{1, \star}$ A. Sorensen,${ }^{3}$ and C. H. Knight ${ }^{3}$ \\ ${ }^{1}$ Grup de Recerca en Remugants, \\ Departament de Ciència Animal i dels Aliments, \\ Universitat Autònoma de Barcelona, 08193 Bellaterra, Spain \\ ${ }^{2}$ Sheep and Goat Research Department, \\ Animal Production Research Institute, \\ 4 Nadi El-Said, 12311 Dokki, Giza, Egypt \\ ${ }^{3}$ Hannah Research Institute, Ayr, KA6 5HL, United Kingdom
}

\begin{abstract}
Fourteen Murciano-Granadina dairy goats were used to evaluate udder compartments (cisternal and alveolar) and cisternal recoil after an oxytocin (OT) challenge at different milking intervals $(8,16$, and $24 \mathrm{~h})$ during wk 7 of lactation. Goats were milked once $(1 \times ; n=7)$ or twice $(2 \times ; n=7)$ daily from wk 2 of lactation. Average milk yields for wk 4 and 8 were 1.76 and $2.24 \mathrm{~L} / \mathrm{d}$, for goats milked $1 \times$ and $2 \times$, respectively. For each half udder, cisternal area was measured by ultrasonography and cisternal milk was measured by machine milking after i.v. injection of an OT receptor blocking agent. Alveolar milk was then obtained after i.v. injection of OT. Regardless of milking frequency, alveolar milk increased from 8 to $16 \mathrm{~h}$ after milking, but did not change thereafter. Cisternal area and cisternal milk increased linearly $\left(\mathrm{R}^{2}=0.96\right.$ to 0.99$)$ up to $24 \mathrm{~h}$, indicating continuous milk storage in the cistern at any alveoli filling degree. Cisternal to alveolar ratio increased with milking interval (from 57:43 to 75:25), but differences between milking intervals were significant at $8 \mathrm{~h}$ only, at which time goats milked $2 \times$ showed a greater ratio $(1 \times=$ 51:49; $2 \times=62: 38$ ). Despite extended milking intervals, cisterns of goats milked $1 \times$ did not become larger than cisterns of goats milked $2 \times$ after 5 wk of treatment. The highest correlation between cisternal area and cisternal milk was detected at $8 \mathrm{~h}$ after milking $(\mathrm{r}=0.74)$. Primiparous goats had smaller cisternal areas and less cisternal milk than multiparous goats at all milking intervals. Cisternal recoil was studied in a sample of multiparous goats milked $1 \times(\mathrm{n}=4)$ and $2 \times(\mathrm{n}=4)$ by scanning cisterns by ultrasonography at $0,5,15$, and $30 \mathrm{~min}$ after an OT challenge for each milking interval. Cisternal area increased after OT injection for the 8- and 16-
\end{abstract}

Received November 11, 2003.

Accepted January 19, 2004.

Corresponding author: G. Caja; E-mail : gerardo.caja@uab.es.

*Present address: Itpsa, Av. de Roma 157, 08011 Barcelona, Spain. $\mathrm{h}$ milking intervals, but no differences were observed for the 24-h interval. Unlike cows, no changes in cisternal area were observed after OT injection, indicating the absence of cisternal recoil in goats. We conclude that goats show a large cisternal compartment that increases linearly after milking. Nevertheless, cisternal size did not increased after $1 \times$ milking, probably because of lesser milk yield. Multiparous goats had larger cisterns than primiparous goats and were able to store more milk in their cisterns at all milking intervals. Because of the high capacity of goat cisterns, no milk return from cistern to alveoli is expected if milking is delayed after milk letdown.

(Key words: ultrasonography, milking frequency, cisternal recoil, goat)

Abbreviation key: $1 \times=$ once daily, $2 \times=$ twice daily, OT = oxytocin.

\section{INTRODUCTION}

Milk in the udder is stored in 2 interconnected compartments (cisternal and alveolar) that determine milkability. Animals with large cisterns are milked faster with simplified routines and tolerate extended milking intervals better (Knight and Dewhurst, 1994; Ayadi et al., 2003; Salama et al., 2003). Milk partitioning between the 2 compartments varies according to species, breed, milking interval, and stage of lactation.

In dairy goats, Peaker and Blatchford (1988) reported elevated cisternal milk percentages, ranging according to time elapsed after milking from $65 \%(1 \mathrm{~h})$ to $88 \%$ $(16 \mathrm{~h})$. Cistern size may become larger in goats after a short period of once daily $(\mathbf{1} \times)$ milking to accommodate greater milk accumulation in the udder (Knight and Dewhurst, 1994). Measurement technique also may affect milk partitioning as a consequence of the possible oxytocin $(\mathbf{O T})$ release during udder manipulation. The use of OT analogues has been proposed to block spontaneous milk ejection (Wellnitz et al., 1999), allowing a reliable separation between cisternal and alveolar milk. 
This is especially critical when milking intervals are long or when machine milking is used instead of teat cannulation to harvest milk fractions separately. Although the methodology of OT blocking agents was validated in Saanen goats (Knight et al., 1994), it has not been used previously in goats for separating cisternal and alveolar milk during different milking intervals.

Cisternal size also has been measured efficiently by ultrasonography in ruminants (Bruckmaier and Blum, 1992; Ruberte et al., 1994; Ayadi et al., 2003). This technique allows noninvasive investigation of the cistern and could be useful as a new approach to study udder changes to accommodate milk accumulation during different milking intervals and after milk letdown.

In mice, Linzell (1955) demonstrated a back-flux of milk from ducts into alveoli when milk removal was delayed after milk letdown as a consequence of the elastic properties of the ducts. This effect was confirmed recently by using real-time ultrasonography in dairy cows and has been termed cisternal recoil (Caja et al., 2003). No references to its occurrence exist in sheep and goats, but Peaker and Blatchford (1988) claimed that because of cisternal recoil, the final distribution of milk in the udder of dairy goats was not affected by repeated OT injections without milking. The aim of the present study was to investigate the effect of milking interval on cisternal size and milk partitioning in the udder of goats adapted to $1 \times$ or twice daily $(\mathbf{2} \times)$ milking. Dairy goats in both milking frequency treatments also were used to test the phenomenon of cisternal recoil.

\section{MATERIALS AND METHODS}

\section{Management of Goats}

Four primiparous and 10 multiparous (2nd parity [ $\mathrm{n}=4$ ] and $\geq 3$ rd parity [ $=6]$ ] Murciano-Granadina dairy goats with symmetrical and healthy udders located on the experimental farm of the S1GCE (Servei de Granges i Camps Experimentals) of the Universitat Autonoma of Barcelona in Bellaterra were used. Goats were allocated at wk 2 of lactation into 2 balanced groups of 7 goats each on the basis of parity and milk yield and assigned randomly to either of 2 milking frequency treatments: $1 \times(0900 \mathrm{~h})$ or $2 \times(0900$ and 1700 h) milkings. During wk 7 of lactation, an experimental period of 5 consecutive d was allowed in which milk partitioning in the udder, cisternal size (from a.m. milking of d 1 to a.m. milking of d 3), and cisternal recoil (from p.m. milking of $d 3$ to a.m. milking of $d 5$ ) were evaluated. After wk 7, each goat was returned to her previous milking frequency treatment until drying off (300 DIM).

Goats grazed natural pastures $(6 \mathrm{~h} / \mathrm{d})$ and were supplemented with concentrates in a shelter with 2 sepa- rate pens allocated according to stage of lactation (Salama et al., 2003). During the 5-d experimental period, goats remained in pens, and their individual daily ration was a dehydrated mixture of whole-plant corn and alfalfa hay fed ad libitum, plus $0.2 \mathrm{~kg}$ of barley grain, 0.3 $\mathrm{kg}$ of alfalfa pellets, and $0.8 \mathrm{~kg}$ of concentrate mixture pellets (1.53 Mcal $\mathrm{NE}_{\mathrm{I}} / \mathrm{kg} ; 16 \% \mathrm{CP}$, as fed). Goats were milked in a double-12 stall parallel milking parlor (Westfalia Surge Ibérica, Granollers, Spain) equipped with recording jars. Typical milking settings were used (vacuum, $42 \mathrm{kPa}$; pulsation rate, 90 pulses/min; and pulsation ratio, $66 \%$ ) for goats of this breed as indicated by Peris et al. (1996). Milking routine included machine milking without udder preparation or teat cleaning, machine stripping, and teat dipping in an iodine solution (P3-cide plus; Henkel Hygiene, Barcelona, Spain). Average milk yield of each goat was calculated by using daily milk records of half udders before (wk 4) and after (wk 8) the experimental period.

\section{Experimental Procedures}

Cisternal size and milk partitioning in the udder. At the end of the a.m. milking of $d 1$, all goats were injected i.v. with 2 IU of OT (Veterin Lobulor, Laboratorios Andreu, Barcelona, Spain) to remove the residual milk in the udder. The following milkings, until the a.m. milking of $d 3$, were used to measure cisternal size and milk partitioning in the half udders (cisternal and alveolar milk) at the following milking intervals: 24,8 , and $16 \mathrm{~h}$ and 8,16 , and $24 \mathrm{~h}$ for goats milked $1 \times$ and $2 \times$, respectively, to minimize changes in the regular milking schedule. Thus, on $d 2$, goats milked $1 \times$ were milked again at $1700 \mathrm{~h}$, corresponding to the 8-h milking interval, whereas goats milked $2 \times$ missed this milking to achieve the 24-h milking interval.

To prevent undesired milk letdown during scanning and evaluation of milk partitioning in the udder, each goat was injected (i.v.) with $0.8 \mathrm{mg}$ of an OT receptor blocking agent (Atosiban; Ferring Lab., Mallmö, Sweden) while in their pens before being taken to the milking parlor. Cisternal size was evaluated for each half udder by measuring cisternal area by ultrasonography. Ultrasonography was conducted using a real time Bmode ultrasonograph (Ultra Scan 900; Ami Medical Alliance Inc., Montreal, Canada) equipped with a $5-\mathrm{MHz}$ sectorial probe $\left(2 \mathrm{~dB}\right.$ power; $80^{\circ}$ scanning angle; 0.5 $\mathrm{mm}$ axial and $1.5-\mathrm{mm}$ lateral resolution). The probe was placed directly against the upper part of the medium suspensory ligament, caudally to the udder, and between the inguinal lymph nodes (Ruberte et al., 1994) using the teat as scan axis. Contact gel was applied to udder skin to exclude air between probe and udder (Geleco Laboratorios Carreras, Barcelona, Spain). Two 
scans were done for each udder half and transferred to a personal computer for image analysis. Cisternal area was calculated in triplicate for each scan using image treatment software (MIP4 Advanced System; Microm España, Barcelona, Spain). A conversion rate of 1024 pixels $/ \mathrm{cm}^{2}$ was used. As the calculated half-life of the OT receptor blocking agent is $18 \mathrm{~min}$ (Wellnitz et al., 1999), a single dose was sufficient to prevent milk letdown, while goats were moved individually to the milking parlor (approximately $4 \mathrm{~min}$ ) to perform duplicated scans for both half udders (approximately $8 \mathrm{~min}$ ) and to evacuate cisternal milk by machine milking ( $<3 \mathrm{~min}$ ). Approximately $20 \mathrm{~min}$ after the Atosiban injection, goats were injected (i.v.) with 2 IU of OT and machinemilked to obtain letdown alveolar milk.

Cisternal recoil. Cisternal recoil phenomenon was studied in 8 (4 per milking frequency) randomly selected multiparous goats using repeated udder scanning after an OT challenge as proposed by Caja et al. (2003). Cisternal recoil was evaluated at 3 milking intervals $(8,16$, and $24 \mathrm{~h})$ for which milk partitioning in the udder was previously measured in both treatments. The experimental period lasted from the p.m. milking of $d \quad 3$ to the a.m. milking of $d 5$.

For the initial udder scanning ( 0 min), each goat was injected (i.v.) with $0.8 \mathrm{mg}$ of Atosiban, and the cistern of each half udder was scanned as previously described. Afterward, 2 IU of OT were injected (i.v.) to induce milk letdown, and cisterns were scanned at 5, 15, and 30 min after injection to measure changes in cisternal area of the unmilked half udders. Two scans were done for each udder half, and cisternal area was calculated in triplicate by using the image treatment software previously indicated. After the last scan, goats were moved to the milking parlor and machine milked.

\section{Statistical Analyses}

Data from half udders were analyzed by ANOVA using mixed model procedure for repeated measurements (PROC MIXED; SAS Inst., Inc., Cary, NC). The mixed model used included the fixed effects of milking frequency (treatment), milking interval, and parity; the random effects of animal and half udder nested within the animal; and the interactions between milking interval and milking frequency and between milking interval and parity plus the residual error. For analyses of the cisternal recoil results, the fixed effect of scanning time after OT injection and the interaction between scanning time and milking interval were added to the model. Pearson's correlation coefficients between measurements were also calculated. Significance was declared as $P<0.05$ unless otherwise indicated.

\section{RESULTS AND DISCUSSION}

\section{Cisternal Area}

Values and changes in cisternal area were not different for each milking intervals in goats milked $1 \times$ and $2 \times$ (Table 1$)$. Cisternal area increased linearly $(P<$ $0.001)$ as milking interval increased in goats milked $1 \times$ $\left(\mathrm{R}^{2}=0.96\right)$ and $2 \times\left(\mathrm{R}^{2}=0.99\right)$. Average cisternal size observed $8 \mathrm{~h}$ after milking $\left(11.1 \pm 1.3 \mathrm{~cm}^{2}\right)$ was slightly smaller than that measured in Saanen goats (Bruckmaier and Blum, 1992) for the same milking interval and probe frequency $(5 \mathrm{MHz})$. At $24 \mathrm{~h}$ after milking, average cisternal area $\left(27.3 \pm 1.4 \mathrm{~cm}^{2}\right)$ increased proportionally to elapsed time (246\%), indicating that cisterns became larger to accommodate milk accumulation in the udder more efficiently. Larger cisternal area may explain the small negative effects of long milking intervals on milk yield previously reported in MurcianoGranadina goats (-17\%; Salama et al., 2003). No references are available describing cisternal size at long milking intervals in different breeds of dairy goats, so the ability of Murciano-Granadina goat udders to adapt to milking $1 \times$ cannot be corroborated.

Although udder halves of goats are much smaller than udder quarters of cows, cisternal area values in our results were similar or greater than those reported by Ayadi et al. (2003) for front quarters of dairy cows (12 to $21 \mathrm{~cm}^{2}$ for 8- to 24 -h milking interval), confirming the importance of cisternal size in dairy goats. Similarly, cisternal area reported at $8 \mathrm{~h}$ in Manchega and Lacaune dairy ewes (14 to $24 \mathrm{~cm}^{2}$; Rovai et al., 2002) and at 24-h milking intervals in Sarda ewes $\left(19 \mathrm{~cm}^{2}\right.$; Nudda et al., 2000) were both greater than those reported in cows.

Significant differences $(P=0.26)$ were not detected between left and right half udder cisternal areas in our machine-milked goats, in contrast to the results of Nudda et al. (2000), who found that left udders had greater cisterns than right udders in hand-milked Sarda dairy ewes. This asymmetry in sheep was attributed to the different stress applied to udder halves during hand milking that was not produced by machine milking in our case.

\section{Milk Partitioning in the Udder}

Average milk yield during the experimental period was normal for the breed (Peris et al., 1996) and losses in milk yield caused by milking $1 \times(-21 \%)$ agree with those reported in Murciano-Granadina goats in early lactation (Salama et al., 2003). Volumes of total milk yield and cisternal milk increased linearly $\left(\mathrm{R}^{2}=0.97\right.$ to $0.99 ; P<0.001$ ) with milking interval up to $24 \mathrm{~h}$ in goats milked both $1 \times$ and $2 \times$ (Table 1 ). Total milk stored 
Table 1. Cisternal size, milk partitioning, and milk accumulation rates at different milking intervals in dairy goats milked once $(1 \times)$ or twice $(2 \times)$ daily (data are least squares means for half udders).

\begin{tabular}{|c|c|c|c|c|c|c|c|}
\hline \multirow[b]{2}{*}{ Item } & \multicolumn{3}{|c|}{$1 \times$} & \multicolumn{3}{|c|}{$2 \times$} & \multirow[b]{2}{*}{ SEM } \\
\hline & $8 \mathrm{~h}$ & $16 \mathrm{~h}$ & $24 \mathrm{~h}$ & $8 \mathrm{~h}$ & $16 \mathrm{~h}$ & $24 \mathrm{~h}$ & \\
\hline Milk yield,${ }^{1} \mathrm{~mL} / \mathrm{d}$ & & $-881^{b}$ & & & $1118^{\mathrm{a}}$ & & 105 \\
\hline Cisternal area, $\mathrm{cm}^{2}$ & $8.7^{\mathrm{c}}$ & $21.9^{\mathrm{b}}$ & $28.3^{\mathrm{a}}$ & $13.4^{\mathrm{c}}$ & $20.4^{\mathrm{b}}$ & $26.2^{\mathrm{a}}$ & 2.5 \\
\hline Cisternal milk, mL & $181^{\mathrm{c}}$ & $469^{\mathrm{b}}$ & $670^{\mathrm{a}}$ & $249^{\mathrm{c}}$ & $453^{\mathrm{b}}$ & $743^{\mathrm{a}}$ & 51 \\
\hline Alveolar milk, mL & $173^{\text {bc }}$ & $234^{\mathrm{a}}$ & $238^{\mathrm{a}}$ & $134^{\mathrm{c}}$ & $209^{\mathrm{ab}}$ & $230^{\mathrm{a}}$ & 23 \\
\hline Total milk, mL & $357^{\mathrm{c}}$ & $706^{\mathrm{b}}$ & $906^{\mathrm{a}}$ & $382^{\mathrm{c}}$ & $661^{\mathrm{b}}$ & $971^{\mathrm{a}}$ & 68 \\
\hline Cisternal fraction, $\%$ & $51^{\mathrm{d}}$ & $66^{\mathrm{bc}}$ & $73^{\mathrm{a}}$ & $62^{\mathrm{c}}$ & $68^{\mathrm{b}}$ & $76^{\mathrm{a}}$ & 2.7 \\
\hline Milk accumulation, $\mathrm{mL} / \mathrm{h}$ & & & & & & & \\
\hline Cisternal & $21.4^{\mathrm{b}}$ & $28.3^{\mathrm{a}}$ & $26.8^{\mathrm{a}}$ & $30.1^{\mathrm{a}}$ & $28.1^{\mathrm{a}}$ & $31.0^{\mathrm{a}}$ & 1.8 \\
\hline Alveolar & $22.0^{\mathrm{a}}$ & $15.0^{\mathrm{bc}}$ & $10.2^{\mathrm{df}}$ & $16.6^{\mathrm{b}}$ & $12.7^{\mathrm{cd}}$ & $9.3^{\mathrm{f}}$ & 1.5 \\
\hline Total & $42.9^{\mathrm{ab}}$ & $42.8^{\mathrm{ab}}$ & $36.6^{\mathrm{c}}$ & $46.8^{\mathrm{a}}$ & $41.0^{\mathrm{bc}}$ & $40.4^{\mathrm{bc}}$ & 1.8 \\
\hline
\end{tabular}

${ }^{1}$ Average half udder milk yield before (wk 4) and after (wk 8) the experimental period.

a,b,c,d,e,f Means with different superscripts within row differ $(P<0.05)$.

in the udder at 8,16 , and $24 \mathrm{~h}$ after milking represented 41,80 and $103 \%$ and 34,59 and $87 \%$ of daily milk yield recorded in goats milked $1 \times$ and $2 \times$, respectively. Daily milk yield calculated by applying the appropriate individual milking interval did not differ from actual daily milk yield at each milking frequency $(1 \times,+3 \% ; P=0.72$; $2 \times,-7 \% ; P=0.28$ ).

Although greater cisternal size was expected in goats milked $1 \times$ to accommodate greater milk accumulation in the udder, as indicated by Knight and Dewhurst (1994) in Saanen goats after a short period of milking $1 \times$, volumes of cisternal milk and cisternal areas did not differ between goats milked $1 \times$ and $2 \times$ at either milking interval. Lack of difference indicates that the 5 -wk period of $1 \times$ milking treatment was not sufficient in Murciano-Granadina goats to produce appreciable changes in cisternal size or that its effect was on the alveolar compartment, which became larger because of the elevated pressure of stored milk (goats milked $1 \times$ stored numerically more milk in the alveoli than goats milked $2 \times$ ).

Volume of alveolar milk increased from the 8- to 16$\mathrm{h}$ milking interval in a similar manner for goats milked both $1 \times$ and $2 \times$ and remained unchanged thereafter (Table 1). These results agree with the pattern of milk accumulation reported in dairy ewes (McKusick et al., 2002) and in dairy cows (Davis et al., 1998; Ayadi et al., 2003) but disagree with those of Peaker and Blatchford (1988) in Saanen dairy goats in which alveolar milk reached a plateau $6 \mathrm{~h}$ after milking. This apparent contradiction could have been due to differences in the experimental techniques used. In the present study, we used an OT receptor blocking agent, whereas Peaker and Blatchford (1988) used direct cannulation without the blocking of OT receptors, which might have induced a transient OT release (Mayer et al., 1991).

Percentage of cisternal milk increased with time since milking for as much as $24 \mathrm{~h}$, but the value at the 8-h milking interval was smaller $(P<0.05)$ in goats milked $1 \times$ than in goats milked $2 \times$ (Table 1$)$. As discussed previously, the decrease in percentage of cisternal milk in goats milked $1 \times$ at $8 \mathrm{~h}$ may be a consequence of their numerically greater alveolar milk fraction at all milking intervals. Percentages of cisternal milk continued to increase at 16 - and 24 -h milking intervals, but differences between groups milked $1 \times$ and $2 \times$ disappeared. Cisternal milk previously reported in Saanen goats milked $2 \times$ (Peaker and Blatchford, 1988; Knight et al., 1994) ranged from $55 \%(1 \mathrm{~h})$ to $85 \%(16 \mathrm{~h})$, which is greater than the average values reported in Table 1 $(8 \mathrm{~h}, 51 \% ; 16 \mathrm{~h}, 68 \%)$ in Murciano-Granadina goats. These differences are less likely to be due to breed differences and more likely due to a consequence of different techniques used to separate milk fractions.

On average, $75 \%$ of total milk stored in the udder at $24 \mathrm{~h}$ after milking was cisternal milk in our study. Although no data exist to compare with our results at this 24-h milking interval in goats, this maximum value was greater than that reported in East Friesian dairy ewes (57\%; McKusick et al., 2002) and in Holstein cows (40\%; Ayadi et al., 2003). A greater cisternal milk percentage was observed in Sarda dairy ewes (82\%; Nudda et al., 2000) at the 24-h milking interval, but this value may be overestimated because the ewes were in late lactation and adrenaline was used as an inhibitor of milk ejection. Knight et al. (1994) reported smaller percentages of cisternal milk using direct teat cannulation or milking after applying an OT receptor blocking agent (57 to $59 \%$ of total milk) than when using adrenalin $(85 \%)$.

Larger cisternal storage capacity observed in the present study in goats allows inhibitory factors of lactation to be diverted away from secretory cells in the alveolar compartment (Wilde et al., 1995). Moreover, large-cisterned udders also reduce alveolar pressure, thus avoiding possible damage to mammary epithelial 
Table 2. Correlations among cisternal area and different milk fractions in Murciano-Granadina dairy goats milked once (above diagonal) or twice (below diagonal) daily.

\begin{tabular}{lrllll}
\hline & $\begin{array}{c}\text { Milking } \\
\text { interval }\end{array}$ & $\begin{array}{l}\text { Cisternal } \\
\text { area }\end{array}$ & $\begin{array}{l}\text { Cisternal } \\
\text { milk }\end{array}$ & $\begin{array}{l}\text { Alveolar } \\
\text { milk }\end{array}$ & $\begin{array}{l}\text { Total } \\
\text { milk }\end{array}$ \\
\hline Cisternal area & 8 & & $0.76^{* *}$ & 0.19 & $0.70^{*}$ \\
& 16 & & $0.68^{*}$ & 0.48 & $0.84^{* * *}$ \\
Cisternal milk & 24 & & 0.29 & 0.20 & 0.30 \\
& 8 & $0.72^{* *}$ & & -0.29 & $0.59^{*}$ \\
& 16 & $0.57^{*}$ & & -0.05 & $0.69^{*}$ \\
Alveolar milk & 24 & 0.42 & & 0.38 & $0.95^{* * *}$ \\
& 8 & $0.69^{* *}$ & $0.61^{*}$ & & $0.76^{* *}$ \\
Total milk & 16 & 0.20 & $0.70^{* *}$ & & $0.69^{*}$ \\
& 24 & 0.39 & $0.61^{*}$ & & $0.65^{*}$ \\
& 8 & $0.77^{* *}$ & $0.96^{* * *}$ & $0.80^{* * * *}$ & \\
& 16 & 0.46 & $0.95^{* * *}$ & $0.88^{* * *}$ & \\
\hline & 24 & 0.46 & $0.98^{* * *}$ & $0.77^{* *}$ & \\
\hline
\end{tabular}

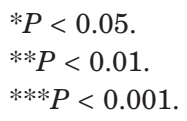

cells (Peaker, 1980) and impairment of their tight junctions (Stelwagen et al., 1994). This high cisternal capacity may explain why loss in milk yield during milking $1 \times$ in medium-cisterned goats, such as Murciano-Granadina dairy goats (-17\%; Salama et al., 2003), is smaller than that in small-cisterned goats, such as Saanen (-26\%; Wilde and Knight, 1990) and Alpine (-35\%; Mocquot, 1978), but greater than that in largecisterned goats, such as Canarian dairy goats (-6\%; Capote et al., 1999). Similarly, cows with a greater cisternal filling at 8-h (Knight and Dewhurst, 1994) and 24-h (Davis et al., 1998) milking intervals were more tolerant to milking $1 \times$.

\section{Correlations Among Cisternal Area and Milk Fractions}

The correlation between cisternal milk volume and cisternal area has not been reported previously in dairy goats. The highest correlation between cisternal milk volume and cisternal area was detected $8 \mathrm{~h}$ after milking (Table 2). But as milking interval increased, correlation between cisternal milk volume and cisternal area decreased in goats milked both $1 \times$ and $2 \times$. Correlations were not significant $24 \mathrm{~h}$ after milking. Similarly, Ayadi et al. (2003) reported that correlations between cisternal milk volume and cisternal area in dairy cows varied quadratically with milking interval, peaking between 8 and $12 \mathrm{~h}$ and hitting a low at $24 \mathrm{~h}$. This quadratic pattern was explained by the fact that, at longer milking intervals, enlarged cisterns could not be completely visualized by ultrasonography as was also true for goats. In our case, milk stored in the large ducts was not included in the estimation of the cisternal area of the udder. Because of the large cisterns observed in goats after the 8-h milking interval (>50\% cisternal milk), correlation between volume of cisternal milk and cisternal area should improve when using a lower frequency probe, which gives a deeper and wider exploration field. Nudda et al. (2000) reported a greater correlation $(\mathrm{r}=0.82 ; 24 \mathrm{~h}$ after milking) in large-cisterned Sarda dairy ewes using a $3.5-\mathrm{MHz}$ probe.

Correlation values in our study were similar to those reported by Rovai et al. (2002) in dairy ewes, but lower than those reported in meat sheep (Caja et al., 1999) or dairy cows (Bruckmaier et al., 1994b; Ayadi et al., 2003), which corresponds with their relatively smallersized cistern. Cisternal area also correlated positively with total milk yield, but only values at $8 \mathrm{~h}$ were significant at both milking frequencies (Table 2). Correlation of cisternal area with alveolar milk also was positive, but was only significant for goats milked $2 \times$ at the 8-h milking interval.

The correlation between milk fractions in the udder supported the role played by the cisterns in milk accumulation. A very high positive correlation between cisternal milk and total milk was observed for goats milked $2 \times$ at all milking intervals, but goats milked $1 \times$ only reached similar values at $24 \mathrm{~h}$ (Table 2 ). This difference indicates that the role of the cistern in storing milk is important at all milking intervals in goats milked $2 \times$. For goats milked $1 \times$, the cistern is more important at longer milking intervals (e.g., $24 \mathrm{~h}$ ), after the alveoli have become full, which agrees with the values reported in Table 1. Cisternal milk correlated positively with alveolar milk in goats milked $2 \times$, but not in goats milked $1 \times$ (Table 2 ).

Correlation coefficients between alveolar milk and total milk were smaller and less affected by milking interval and milking frequency than the correlation between cisternal milk and total milk (Table 2). This difference indicates that the milk yield potential of the alveolar compartment may be not expressed if the size of the cisternal compartment or the milking frequency prevents milk drainage from the alveoli.

\section{Effect of Parity Number on Cistern Size and Milk Partitioning in the Udder}

Values of cisternal area and cisternal milk volume according to time after milking in primiparous and multiparous goats are shown in Figure 1. Primiparous goats had smaller cisternal area and lesser cisternal milk than multiparous goats ( 15.0 vs. $22.3 \mathrm{~cm}^{2} ; 330$ vs. 512 $\mathrm{mL}$, respectively; $P<0.01$ ). Although no data exist for comparison with goats, our results are in accordance with the trend reported in dairy cows (Bruckmaier et al., 1994b; Pfeilsticker et al., 1996) and in dairy ewes (Rovai et al., 2002), suggesting an enlargement of the 

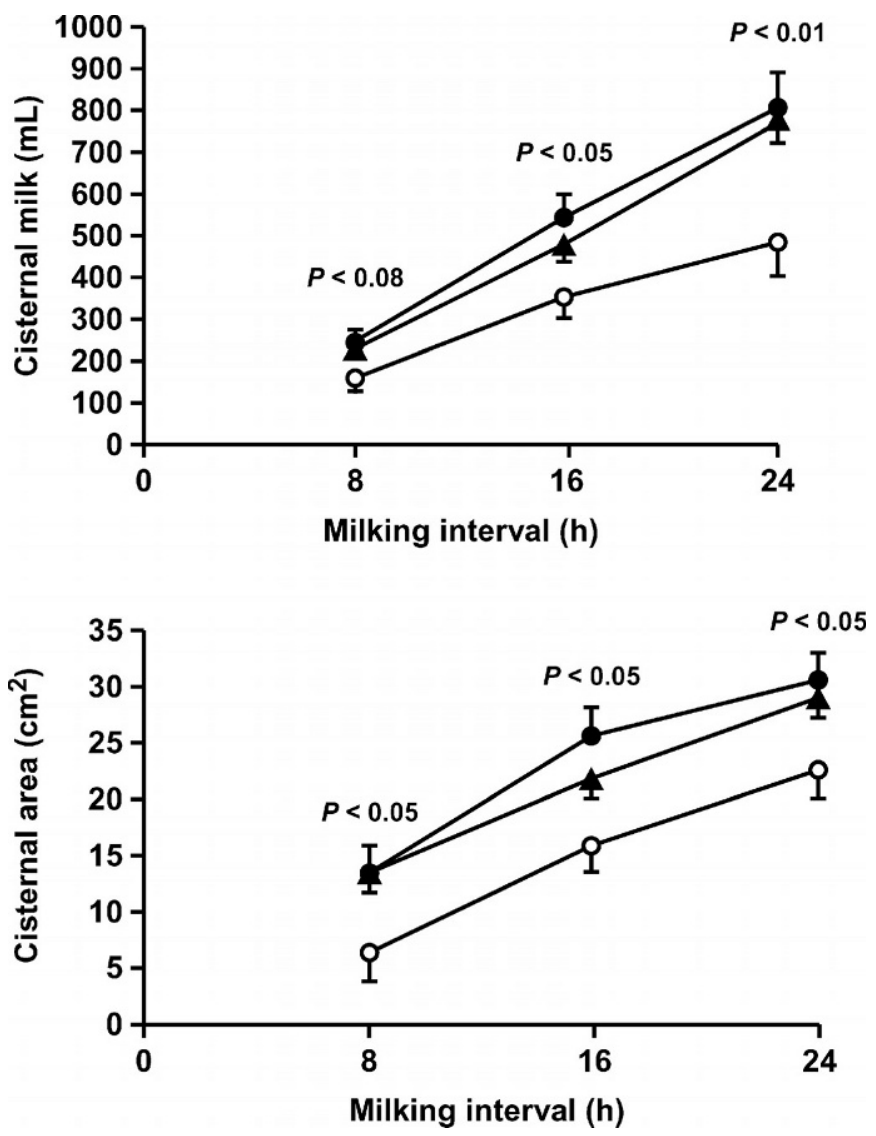

Figure 1. Effect of milking interval on cisternal milk (upper panel) and cisternal area (lower panel) by half udder based on parity number: $\bigcirc=1$ st parity $(\mathrm{n}=4) ; \boldsymbol{O}=2$ nd parity $(\mathrm{n}=4) ; \boldsymbol{\Delta}=\geq 3$ rd parity $(\mathrm{n}=$ 6). Vertical bars represent SE.

mammary cistern with increasing age. Differences in storage capacity of the cisterns between primiparous and multiparous goats were more evident after $24 \mathrm{~h}$ of milk accumulation, in which multiparous goats had larger cisternal area $\left(29.9\right.$ vs. $\left.22.6 \mathrm{~cm}^{2} ; P<0.05\right)$ and were able to store more volume of milk in the cistern (791 vs. $481 \mathrm{~mL} ; P<0.01$ ) than primiparous goats. Moreover, after $24 \mathrm{~h}$ of milk accumulation, parity number correlated positively with cisternal area $(\mathrm{r}=0.44$; $P<0.05$ ), cisternal milk ( $\mathrm{r}=0.56 ; P<0.01)$, alveolar milk ( $\mathrm{r}=0.35 ; P<0.08)$, and total milk $(\mathrm{r}=0.57 ; P<$ 0.01 ). These results suggest that smaller cisterns would be full sooner to cause greater intra-alveolar pressure and more autocrine factors in milk (putative feedback inhibitor of lactation), which is only effective in the alveolar compartment (Wilde et al., 1995) to inhibit milk secretion. Our data agree with the previous results in which primiparous goats milked $1 \times$ suffered greater losses $(-30 \%)$ than older goats $(-11 \%$; Salama et al., 2003).
Table 3. Change in cisternal area measured by ultrasonography after an oxytocin challenge on the basis of milking interval in dairy goats (data are least squares means for half udders in $\mathrm{cm}^{2}$ ).

\begin{tabular}{llllll}
\hline \multirow{2}{*}{$\begin{array}{l}\text { Milking } \\
\text { interval, h }\end{array}$} & \multicolumn{4}{c}{ Time after i.v. oxytocin (min) } \\
\cline { 2 - 5 } & 0 & 5 & 15 & 30 & SEM \\
\hline 8 & $14.4^{\mathrm{b}, \mathrm{d}}$ & $25.4^{\mathrm{a}, \mathrm{d}}$ & $25.8^{\mathrm{a}}$ & $24.2^{\mathrm{a}, \mathrm{d}}$ & 2.1 \\
16 & $24.9^{\mathrm{b}, \mathrm{c}}$ & $29.6^{\mathrm{a}, \mathrm{c}}$ & $29.5^{\mathrm{a}}$ & $29.5^{\mathrm{a}, \mathrm{c}}$ & 2.0 \\
24 & $28.4^{\mathrm{c}}$ & $30.2^{\mathrm{c}}$ & 29.2 & $30.0^{\mathrm{c}}$ & 2.1 \\
\hline \multicolumn{4}{c}{${ }^{\mathrm{a}, \mathrm{b}}$ Means with different superscripts within row $\operatorname{differ}(P<0.05)}$. \\
\multicolumn{4}{c}{ c,d Means with different superscripts within column $\operatorname{differ}(P<0.05)}$.
\end{tabular}

\section{Cisternal Recoil}

Cisternal area changes produced according to time since the OT challenge are shown in Table 3. Milking frequency did not affect cisternal area, and interaction between treatment and milking interval also was not significant. Therefore, data from both treatments were analyzed jointly ( $\mathrm{n}=8$ goats).

Initial cisternal area (before OT injection) was smaller $(P<0.05)$ for the 8 -h than the 16 - and 24 $\mathrm{h}$ milking intervals, but no differences were detected between 16 and $24 \mathrm{~h}$. Cisternal areas reached their greatest values $\left(29.5 \mathrm{~cm}^{2}\right.$, on average $)$ for the 24 -h milking interval and did not vary at any time point, suggesting that the maximum cisternal storage capacity was reached after $24 \mathrm{~h}$ of milk accumulation regardless the milking frequency. However, cisternal area increased 5 min after the OT injection for the 8-h (79\%, $P<0.001)$ and 16 -h $(19 \%, P<0.05)$ milking intervals, but remained constant thereafter, indicating that the cisternal recoil phenomenon reported by Caja et al. (2003) in dairy cows was not produced in goats. Lack of cisternal recoil in goats agrees with another report (Pfeilsticker et al., 1996), in which no change in the amount of cisternal milk occurred for as much as 120 min after teat stimulation in dairy cows. Moreover, the greater cisternal milk percentages detected in our goats (ranging from 51 to $76 \%$ of total milk) and the small contact surface between the alveolar and cisternal compartments made the return of a significant amount of cisternal milk to the alveoli difficult. These results confirm the general statement of good milkability of dairy goats and their weak dependency on OT release for milk removal (Bruckmaier et al., 1994a).

\section{CONCLUSIONS}

Cisternal changes according to time after milking were easily monitored by udder scanning (after $8 \mathrm{~h}$ of milk storage) in dairy goats. No apparent changes in the storage characteristics of the cisternal compartment of the udder of dairy goats were observed as a consequence 
of $1 \times$ milking during early lactation. Multiparous goats had greater cisternal area and are able to store more milk in the cisternal compartment than primiparous goats. No cisternal recoil occurs in goats, indicating that, once milk is ejected, it is unable to return to the alveoli regardless whether milking is performed.

\section{ACKNOWLEDGMENTS}

This work was part of a European Commission-DG Agriculture (Agri) research project (FAIR 1, CT950881) and was also supported by a research scholarship to A. A. K. Salama from the Agencia Española de Cooperación Internacional (AECI) of Spain. The authors also are grateful to Ramon Costa and his staff at the S1GCE (Servei de Granges i Camps Experimentals) of the UAB for the care of the animals and to Nic Aldam for reviewing the manuscript.

\section{REFERENCES}

Ayadi, M., G. Caja, X. Such, and C. H. Knight. 2003. Use of ultrasonography to estimate cistern size and milk storage at different milking intervals in the udder of dairy cows. J. Dairy Res. 70:1-7.

Bruckmaier, R. M., and J. W. Blum. 1992. B-mode ultrasonography of mammary glands of cows, goats and sheep during $\alpha$ - and $\beta$ adrenergic agonist and oxytocin administration. J. Dairy Res. 59:151-159.

Bruckmaier, R. M., C. Ritter, D. Schams, and J. W. Blum. 1994a. Machine milking of dairy goats during lactation: Udder anatomy, milking characteristics, and blood concentrations of oxytocin and prolactin. J. Dairy Res. 61:457-466.

Bruckmaier, R. M., E. Rothenanger, and J. W. Blum. 1994b. Measurement of mammary gland cistern size and determination of the cisternal milk fraction in dairy cows. Milchwissenschaft 49:543-546.

Caja, G., X. Such, J. Ruberte, A. Carretero, and M. Navarro. 1999. The use of ultrasonography in the study of mammary gland cisterns during lactation in sheep. Pages 91-93 in Milking and Milk Production of Dairy Sheep and Goats. F. Barillet and N. P. Zervas, ed. Wageningen Pers, Wageningen, The Netherlands.

Caja, G., M. A. Ayadi, and C. H. Knight. 2003. Evidence of cisternal recoil after milk letdown in the udder of dairy cows. J. Dairy Sci. 86(Suppl. 1):117.(Abstr.)

Capote, J., J. L. López, G. Caja, S. Peris, A. Argüello, and N. Darmanín. 1999. The effects of milking once or twice daily throughout lactation on milk production of Canarian dairy goats. Pages 267273 in Milking and Milk Production of Dairy Sheep and Goats. F. Barillet and N. P. Zervas, ed. Wageningen Pers, Wageningen, The Netherlands.

Davis, S. R., V. C. Farr, P. J. A. Copeman, V. R. Carruthers, C. H. Knight, and K. Stelwagen. 1998. Partitioning of milk accumulation between cisternal and alveolar compartments of the bovine udder: Relationship to production loss during once daily milking. J. Dairy Res. 65:1-8.

Knight, C. H., and R. J. Dewhurst. 1994. Once daily milking of dairy cows: Relationship between yield loss and cisternal milk storage. J. Dairy Res. 61:441-449.

Knight, C. H., K. Stelwagen, V. C. Farr, and S. R. Davis. 1994. Use of an oxytocin analogue to determine cisternal and alveolar milk pool sizes in goats. J. Dairy Sci. 77(Suppl. 1): 84. (Abstr.)

Linzell, J. L. 1955. Some observations on the contractile tissue of the mammary glands. J. Physiol. 130:257-267.

Mayer, H., R. Bruckmaier, and D. Schams. 1991. Lactational changes in oxytocin release, intramammary pressure and milking characteristics in dairy cows. J. Dairy Res. 58:159-169.

McKusick, B. C., D. L. Thomas, Y. M. Berger, and P. G. Marnet. 2002. Effect of milking interval on alveolar versus cisternal milk accumulation and milk production and composition in dairy ewes. J. Dairy Sci. 85:2197-2206.

Mocquot, J. C. 1978. Effets de l'omission régulière et irrégulière d'une traite sur la production laitière de la chèvre. Pages 175-201 in Proc. 2nd Int. Symp. Milking Small Ruminants, Alghero, Italy.

Nudda, A., G. Pulina, R. Vallebella, R. Bencini, and G. Enne. 2000. Ultrasound technique for measuring mammary cistern size of dairy ewes. J. Dairy Res. 67:101-106.

Peaker, M. 1980. The effect of raised intramammary pressure on mammary function in the goat in relation to the cessation of lactation. J. Physiol. 301:415-428.

Peaker, M., and D. R. Blatchford. 1988. Distribution of milk in the goat mammary gland and its relation to the rate and control of milk secretion. J. Dairy Res. 55:41-48.

Peris, S., X. Such, and G. Caja. 1996. Milkability of Murciano-Granadina dairy goats. Milk partitioning and flow rate during machine milking according to parity, prolificacy and mode of suckling. J. Dairy Res. 63:1-9.

Pfeilsticker, H. U., R. M. Bruckmaier, and J. W. Blum. 1996. Cisternal milk in the dairy cow during lactation and after preceding teat stimulation. J. Dairy Res. 63:509-515.

Rovai, M., X. Such, G. Caja, and J. Piedrafita. 2002. Changes in cisternal and alveolar milk throughout lactation in dairy sheep. J. Dairy Sci. 85 (Suppl.1): 4.(Abstr.)

Ruberte, J., A. Carretero, M. Fernández, M. Navarro, G. Caja, F. Kirchner, and X. Such. 1994. Ultrasound mammography in the lactating ewe and its correspondence to anatomical section. Small Ruminant Res. 13:199-204.

Salama, A. A. K., X. Such, G. Caja, M. Rovai, R. Casals, E. Albanell, M. P. Marin, and A. Marti. 2003. Effects of once versus twice daily milking throughout lactation on milk yield and milk composition in dairy goats. J. Dairy Sci. 86:1673-1680.

Stelwagen, K., S. R. Davis, V. C. Farr, C. G. Prosser, and R. A. Sherlock. 1994. Mammary epithelial cell tight junction integrity and mammary blood flow during an extended milking interval in goats. J. Dairy Sci. 77:426-432.

Wellnitz, O., R. M. Bruckmaier, C. Albrecht, and J. W. Blum. 1999. Atosiban, an oxytocin receptor blocking agent: Pharmacokinetics and inhibition of milk ejection in dairy cows. J. Dairy Res. 66:1-8.

Wilde, C. J., and C. H. Knight. 1990. Milk yield and mammary function in goats during and after once-daily milking. J. Dairy Res. 57:441-447.

Wilde, C. J., C. V. P. Addey, L. M. Boddy, and M. Peaker. 1995. Autocrine regulation of milk secretion by a protein in milk. Biochem. J. 305:51-58. 